\title{
Review
}

\section{Fibroblast biology}

Signals targeting the synovial fibroblast in arthritis

Yrjö T Konttinen ${ }^{\star \neq}$, Tian-Fang Li*, Mika Hukkanen*, Jian Ma*+, Jing-Wen Xu* and Ismo Virtanen*

\author{
*Institute of Biomedicine and 'Institute of Dentistry, University of Helsinki, \\ and $¥$ Surgical Hospital, Helsinki, Finland
}

\begin{abstract}
Fibroblast-like cells in the synovial lining (type B lining cells), stroma and pannus tissue are targeted by many signals, such as the following: ligands binding to cell surface receptors; lipid soluble, small molecular weight mediators (eg nitric oxide [NO], prostaglandins, carbon monoxide); extracellular matrix (ECM)-cell interactions; and direct cell-cell contacts, including gap junctional intercellular communication. Joints are subjected to cyclic mechanical loading and shear forces. Adherence and mechanical forces affect fibroblasts via the ECM (including the hyaluronan fluid phase matrix) and the pericellular matrix (eg extracellular matrix metalloproteinase inducer [EMMPRIN]) matrices, thus modulating fibroblast migration, adherence, proliferation, programmed cell death (including anoikis), synthesis or degradation of ECM, and production of various cytokines and other mediators [1]. Aggressive, transformed or transfected mesenchymal cells containing proto-oncogenes can act in the absence of lymphocytes, but whether these cells represent regressed fibroblasts, chondrocytes or bone marrow stem cells is unclear.
\end{abstract}

Keywords: fibroblast, rheumatoid arthritis, synovial membrane

\section{Soluble mediators binding to cell surface receptors \\ Cytokine network and signal transduction}

Cytokines bind to their receptors, activating signal transduction pathways such as adenylate cyclase/cAMP, phospholipase C/inositol trisphosphate, and $\mathrm{Ca}^{2+}$ and tyrosine kinases. Cytokines can stimulate random migration (chemokinesis), guided fibroblast migration along a concentration gradient (chemokinesis; Table 1) [2-15] and/or fibroblast proliferation (Table 2) [16-25]. Regulation of fibroblast migration and proliferation is not straightforward; the effect may be indirect or dependent on concentration and the cytokine network. Some cytokines act as competence rather than progression factors, some lack secretory signals, and some must be processed and released from the pericellular matrix or basement membranes (eg transforming growth factor beta [TGF- $\beta$ ] binding to chondroitin or the keratan sulfate of biglycan, decorin and fibromod-

$\mathrm{COX}=$ cyclooxygenase; $\mathrm{ECM}=$ extracellular matrix; EMMPRIN = extracellular matrix metalloproteinase inducer; $\mathrm{HO}=$ hemeoxygenase; IFN- $\gamma=$ interferon gamma; IL = interleukin; iNOS = inducible nitric oxide synthase; MMP = matrix metalloproteinase; NADPH = nicotinamide adenine dinucleotide phosphate; $\mathrm{NO}=$ nitric oxide; NOS = nitric oxide synthase; TGF- $\beta=$ transforming growth factor beta; TIMP $=$ tissue inhibitor of metalloproteinase; TNF- $\alpha=$ tumor necrosis factor alpha. 
Table 1

\begin{tabular}{|c|c|c|c|}
\hline Effect & Factor & Cellular or tissue source & Reference \\
\hline+ & TNF- $\alpha$ & Macrophage, activated monocyte, B cell, T cell, fibroblast & [2] \\
\hline+ & $\mathrm{IL}-4$ & T cell, mast cell, bone marrow stromal cell & [3] \\
\hline+ & PDGF-AA, -BB, -AB & $\begin{array}{l}\text { Platelet, macrophage, endothelial cell, skeletal muscle cell, fibroblast, vascular smooth } \\
\text { muscle cell, glial cell, type I astrocyte, myoblast, kidney, epithelial cell, mesangial cell }\end{array}$ & [3] \\
\hline+ & TGF- $\beta$ & Platelet, macrophage, T cell, skeletal muscle cell, fibroblast & [4] \\
\hline+ & bFGF & Brain, retina, bone matrix, endothelial cell, macrophage & [3] \\
\hline+ & EGF & Granulocyte, ectodermal cell, kidney, duodenal gland, platelet & [5] \\
\hline+ & Neurokinin A & Nerve cell & [3] \\
\hline+ & CGRP & Nerve cell & [6] \\
\hline+ & Endothelin-1 and -3 & Endothelial cell, macrophage, fibroblast, many other cells & [3] \\
\hline+ & $\beta$-thromboglobulin & Platelet, megakaryocyte & [1] \\
\hline+ & Platelet factor 4 & Platelet, megakaryocyte & [1] \\
\hline+ & $\mathrm{LTB}_{4}$ & Myeloid cells, from transported LTA 4 in many nonmyeloid and nonhematopoietic cells & [3] \\
\hline+ & IGF-I (SmC) & Fibroblast, skeletal cell, liver, endothelial cell, T cell & [7] \\
\hline+ & IGF-II (MSA) & Liver & [3] \\
\hline+ & $\begin{array}{l}\text { Matrix proteins } \\
\text { Collagen } \\
\text { Fibronectin } \\
\text { Elastin }\end{array}$ & $\begin{array}{l}\mathrm{ECM} \\
\mathrm{ECM} \\
\mathrm{ECM}\end{array}$ & $\begin{array}{l}{[8]} \\
{[9]} \\
{[10]}\end{array}$ \\
\hline+ & $\begin{array}{l}\text { Serum derived } \\
\text { chemotactic factor } \\
\text { for fibroblasts }\end{array}$ & Complement $\left(\mathrm{C}_{5}\right)$ & {$[11,12]$} \\
\hline- & Interferon & T lymphocyte, NK cell (interferon- $\gamma$ ), all cells (interferon- $\alpha$ ) & [13] \\
\hline- & Retinoids & & [14] \\
\hline- & Neutrophil factor & Neutrophil & [15] \\
\hline
\end{tabular}

+, Stimulation; -, inhibition. bFGF, basic fibroblast growth factor; CGRP, calcitonin gene-related peptide; ECM, extracellular matrix; EGF, epidermal growth factor; IGF, insulin-like growth factor; IL, interleukin; LTA, leukotriene A; LTB, leukotriene B; NK, natural killer; PDGF, platelet derived growth factor; TGF, transforming growth factor; TNF, tumor necrosis factor.

ulin, or basic fibroblast growth factor and platelet derived growth factor binding to the heparin sulfate of glypican, perlecan and syndecan).

\section{Matrix deposition}

The TGF- $\beta$ family forms an important group of growth factors, consisting of three isoforms in man, and is important for matrix deposition because it modulates fibroblast recruitment and proliferation. This growth factor also stimulates production of collagens, proteoglycans, elastin, fibronectin, tenascin and thrombospondin, diminishes production of extracellularly active neutral endoproteinases belonging to the matrix metalloproteinase (MMP) and serine proteinase families, and stimulates production of endogenous MMP inhibitors (tissue inhibitor of metalloproteinase [TIMP]) and serpins (plasminogen activator inhibitor-1). Other profibrotic, collagen synthesis stimulat- ing cytokines include endothelin, interleukin (IL)-1 and mast cell tryptase. Interferons and IL-4 decrease collagen synthesis. In addition to IL-4, 'biologicals' such as humanized anti-TGF- $\beta$ antibodies and recombinant human interferons are, accordingly, being tested as a treatment for fibrotic diseases.

\section{Matrix degradation}

Fibroblasts produce proteolytic enzymes (in particular, MMPs). MMPs now comprise a group of 18 different enzymes in man, including the classic fibroblast collagenase MMP-1 (collagenase-1), the mesenchymal form of MMP-8 (collagenase-2) and MMP-13 (collagenase-3). MMP-8 was known as neutrophil collagenase until it was found to be produced by tumor necrosis factor $\alpha$ (TNF- $\alpha$ ) stimulated fibroblasts, for example, although in a less glycosylated form (50 kDa instead of $75 \mathrm{kDa}$ ) [26]. Co- 
Table 2

\begin{tabular}{|c|c|c|c|}
\hline Effect & Factors & Examples of cellular and tissue source & Reference \\
\hline+ & AMDGF & Alveolar macrophage & [16] \\
\hline+ & aFGF, bFGF & Brain, retina, bone matrix, endothelial cells, macrophage & [17] \\
\hline+ & CTAP-III & Platelet & \\
\hline+ & CTAP-V & Platelet & \\
\hline+ & CTAP-PMN & PMN & \\
\hline+ & EGF and TGF- $\alpha$ & Granulocyte, ectodermal cells, kidney, duodenal gland, platelet & [18] \\
\hline- & Interferon- $\gamma$ & T lymphocyte, NK cell & [19] \\
\hline+ & IGF-I (SmC) & Fibroblast, skeletal cell, liver, endothelial cell, T cell & [20] \\
\hline+ & IGF-II (MSA) & Liver & [21] \\
\hline+ & IL- $1 \alpha$ and IL- $\beta$ & $\begin{array}{l}\text { Monocyte/macrophage, Langerhans cell, other dendritic cells, T lymphocyte, B lymphocyte, } \\
\text { NK cell, large granular lymphocyte, vascular endothelial cell, smooth muscle cell, fibroblast, } \\
\text { thymic epithelial cell, astrocyte, microglia, keratinocyte, chondrocyte }\end{array}$ & \\
\hline+ & IL-1 inhibitor & Monocyte & [22] \\
\hline+ & $\begin{array}{l}\text { PDGF-AA, PDGF-BB, } \\
\text { PDGF-AB }\end{array}$ & $\begin{array}{l}\text { Platelet, macrophage, endothelial cell, fibroblasts, vascular smooth cells, glial cell, type I astrocyte, } \\
\text { kidney, epithelial cell, mesangial cells }\end{array}$ & \\
\hline+ & TCDGF & T cell & [23] \\
\hline+ & TGF- $\beta$ & Platelets, macrophage, $\mathrm{T}$ cell, skeletal muscle cell, fibroblast & {$[24]$} \\
\hline+ & TNF- $\beta$ & Lymphocyte & {$[25]$} \\
\hline
\end{tabular}

+, Stimulation; -, inhibition. aFGF, acidic fibroblast growth factor; AMDGF, alveolar macrophage-derived growth factor; bFGF, basic fibroblast growth factor; CTAP, connective tissue-activating peptide; EGF, epidermal growth factor; IGF, insulin-like growth factor; IL, interleukin; NK, natural killer; PDGF, platelet derived growth factor; PMN, polymorphonuclear cell; TCDGF, T cell derived growth factor; TGF, transforming growth factor; TNF, tumor necrosis factor.

localization of TNF and its receptors in synovial tissue and at the cartilage-pannus junction may play a role in the pathogenesis of rheumatoid arthritis [27]. Fibroblasts produce TIMPs (1-4), which were previously called human fibroblast collagenase inhibitors. TIMP-1 is induced by inflammatory cytokines IL- 1 and TNF- $\alpha$, but also by TGF- $\beta$, progesterone and estrogen. IL- 6 , interestingly, does not seem to stimulate the production of collagenase, but is a potent inducer of TIMP-1.

\section{Lipid soluble mediators penetrating the cell membrane}

$\mathrm{NO}$ is a freely diffusible radical gas, which is a product of the catalytic conversion of $\mathrm{L}$-arginine to $\mathrm{L}$-citrulline by nitric oxide synthases (NOS) (EC 1.14.13.39) via the chemical reaction between the guanidino-nitrogen of L-arginine and dioxygen. The activity of the inducible NO synthase (iNOS) requires pro-inflammatory cytokines such as IL-1 and TNF- $\alpha$ for upregulation of mRNA and protein. The activity of iNOS, in turn, is under strict control of nicotinamide adenine dinucleotide phosphate (NADPH), flavine adenidine dinucleotide, flavin mononucleotide, heme and $5,6,7,8$-tetrahydrobiopterin for activity [28]. The iNOS is highly expressed in the rheumatoid synovium, particularly in synovial fibroblasts $[29,30]$. The mRNA initiation site of the iNOS gene is preceded by a promoter sequence box, along with two distinct regions upstream containing consensus sequences for the binding of various transcription factors. Region 1 contains lipopolysaccharide responsive elements such as the binding sites for nuclear factor-1, IL-6 and NF-KB, indicating a locus for LPS induced synthesis of iNOS. Region 2 contains motifs for interferon gamma (IFN- $\gamma$ )-regulated transcription factors but does not directly regulate induction of iNOS; instead, it subserves region 1. LPS therefore stimulates iNOS synthesis directly, and IFN- $\gamma$ acts in synergy with LPS to augment iNOS synthesis and NO production. This synergy also extends to the cytokines IL-1 and TNF- $\alpha$, which, in combination with IFN- $\gamma$, augment the synthesis of iNOS and NO [31]. Apoptosis induced by NO is associated with nuclear p53 protein expression in cultured human fibroblasts [32]. $\mathrm{NO}$ can also induce the synthesis and activity of cyclooxygenase (COX)-2 and hemeoxygenase (HO)-1.

Prostaglandin $\mathrm{H}_{2}\left(\mathrm{PGH}_{2}\right)$ synthase (EC 1.14.99.1) has two activities, COX and peroxidase, and occurs in two isoforms, known as COX-1 and COX-2 [33]. The inducible COX-2 mRNA and protein are stimulated largely by the 
same factors as iNOS, such as IL-1, TNF- $\alpha$ and IFN- $\gamma$ [34]. The promoter region of COX-2 contains binding sites for NF-KB, NF-IL6 and two motifs for IFN- $\gamma$ activated sequences [34]. $P G E_{2}$ and $P E_{1}$ inhibit cytokine-induced metalloproteinase expression in human synovial fibroblasts [35]. COX inhibition conversely enhances the production of pro-MMP-1 in human rheumatoid synovial fibroblasts [36]. $\mathrm{PGE}_{2}$ also enhances the synthesis of IL-8 and IL-6, but inhibits granulocyte-macrophage colony-stimulating factor production by IL-1 stimulated synovial fibroblasts [37].

Carbon monoxide is produced by two homologous microsomal HO (EC 1.14.93) isoenzymes: inducible HO-1 (heat shock protein-32) and constitutively expressed HO-2. The latter is widely expressed in fibroblasts, and $\mathrm{HO}-1$ can be induced in these and other cell types by hypoxia and free radicals [38]. HO-1 prevents cell death by regulating intracellular iron levels. $\mathrm{HO}$ functions by cleaving heme to biliverdin and carbon monoxide, in the presence of NADPH and NADPH-cytochrome $\mathrm{P}_{450}$, with equimolar iron released from the heme as a co-product [39]. There is a regulatory loop between iron metabolism and the NO pathway: intracellular ferric iron $\left(\mathrm{Fe}^{3+}\right)$ levels can significantly decrease iNOS mRNA transcription, and iron chelating agents like desferrioxamine can increase iNOS transcription and NO production [40]. NO itself, conversely, can directly control intracellular iron metabolism by activating the iron-regulatory protein involved in ferritin translocation. Therefore, the interplay between iNOS and $\mathrm{HO}-1$ activities may have far-reaching consequences in situations characterized by oxidative stress.

\section{Extracellular matrix, and integrin and nonintegrin receptors}

The ECM-cell interactions are coupled to cytoskeletal elements, such as $\alpha$-actinin, talin and tensin, and affect various tyrosine kinases, for example focal adhesion kinases, Src (the protein product of the src gene of the Rous sarcoma virus) family kinases and Crk (the protein product of the crk gene from chicken retroviruses CT10 and ASV-1). Focal adhesion kinases provide a potent anoikis resistance factor [41], anoikis referring to apoptosis caused by loss of ECM-cell adhesion. ECM-fibroblast interactions are important because the synovial lining cells and the pannus are subjected to shear stress. Synovial cells are also subjected to cyclic mechanical loading during the movement of the joint.

The synovial ECM provides hydraulic resistance, preventing rapid seepage of synovial fluid out of the joint cavity, and modifies the traffic of macromolecules. It may trap antigens, which contribute to inflammation. The three main classes of synovial structural polymers are collagen (scaffolding), extrafibrillar glycosaminoglycans/proteoglycans and structural glycoproteins. Under normal circumstances, collagen is hidden in a matrix created by the latter two classes. Fibronectin guides fibroblast migration as an immobilized substrate and attractant in the leading edge of the pannus (haptotaxis) [42]. The extra domain-A fibronectin isoform is associated with the activated, transformed state of type B lining cells [43]. The interaction between connecting sequence-1 fibronectin (or vascular cell adhesion molecule-1) and $\alpha 4 \beta 1$ (very late activation antigen-4) may play a role in the proliferation of synovial lining and lymphocyte migration [44]. EMMPRIN $\left(M_{r} \approx 58000\right)$ is an integral plasma membrane glycoprotein of the pericellular matrix belonging to the immunoglobulin superfamily, previously referred to as tumor-cell derived collagenase stimulatory factor. It is identical to the M6 leukocyte activation antigen, and highly homologous to rat OX-47 or CE9, mouse basigin or gp42, and chicken HT-7 or neurothelin molecules. Reciprocal immunoprecipitation, cell surface crosslinking and immunofluorescence colocalization experiments demonstrated that EMMPRIN can form a complex with integrins $\alpha 3 \beta 1$ and $\alpha 6 \beta 1$, which may play a role in the synovial membrane [45]. Many other ECM-fibroblast interactions are of potential relevance in the synovial membrane (Table 3) [46-61].

The most important receptor family binding and responding to ECM is formed by integrins, which are heterodimeric molecules comprising, to date, 16 alpha and 8 beta subunits. The $\beta_{1}$ integrins bind collagens, laminins, entactin/nidogen, fibronectin, tenascin and vascular cell adhesion molecule- 1 , whereas $\beta_{2}$ integrins are mainly expressed in blood leukocytes and perform a role in both immune inflammation, and in heterotypic interactions of fibroblasts with other cells. The $\alpha_{v}$ integrins mediate adhesion to provisional matrix molecules, such as fibrinogen, fibronectin, vitronectin, thrombospondin and osteopontin. In addition to these three major subclasses, $\alpha_{6} \beta_{4}$ integrin, as a component of hemidesmosomes, forms a receptor for laminin-5 and laminin-10. The $\alpha_{111} \beta_{3}$ and $\alpha_{4} \beta_{7}$ integrins, as well as $\alpha_{E} \beta_{7}$ integrin, perform roles in platelet function and vascular adhesion, respectively [41]. Integrin subunits $\alpha_{3}$, $\alpha_{4}, \alpha_{5}, \alpha_{6}, \alpha_{v}$ and $\beta_{1}$ are overexpressed in synovitis [48]. Nonintegrin receptors, such as CD44, binding hyaluronan, and also other ligands (such as collagens I and $\mathrm{VI}$ ), are of importance in this respect. CD44-hyaluronan interaction modulates the migration of inflammatory leukocytes into the extravascular compartment of the synovial membrane.

\section{Cell-cell interactions}

Direct cell-cell interactions are typical for epithelial cells, but direct cell-cell contacts have been considered rare in connective tissue. Connective tissue cells such as fibroblasts were thought to be regulated not only by soluble factors, but also by effects resulting from ECM-fibroblast interactions. However, time-lapse cinephotomicrography and light and electron microscopy have been used to show close physical apposition and adhesion between fibroblasts and other cells. This adhesion is not only a 
Table 3

Interactions between extracellular matrix (ECM) proteins and fibroblast-like synoviocytes (FLS)

\begin{tabular}{|c|c|c|}
\hline ECM & Effect & Reference \\
\hline \multirow[t]{3}{*}{ Laminin (Ln) } & Ln is synthesized in rat and human FLS, and is involved in FLS adhesion & {$[46]$} \\
\hline & FLS adhesion to Ln shows enhanced proliferative ability in response to PDGF & [47] \\
\hline & $\begin{array}{l}\text { RA-FLS bind to Ln more strongly than normal FLS, with monoclonal antibodies to integrin } \alpha 3, \alpha 6 \text {, } \\
\beta 1 \text { subunits partly blocking this adhesion }\end{array}$ & [48] \\
\hline \multirow[t]{7}{*}{ Fibronectin (Fn) } & $\begin{array}{l}\text { FLS plated on the substrate containing Fn show extensive focus formation, and enhanced adhesion } \\
\text { and proliferation }\end{array}$ & [49] \\
\hline & CS-1 Fn correlates with FLS proliferation & [50] \\
\hline & ED-A Fn is associated with activation of FLS & [44] \\
\hline & FLS adhering to Fn show higher proliferative ability in response to PDGF & [43] \\
\hline & Adhesion to $\mathrm{Fn}$ through integrin $\alpha 5 \beta 1$ downregulates the collagenase expression in human FLS & [47] \\
\hline & $\begin{array}{l}\text { RA-FLS bind more strongly to Fn than normal FLS; anti- } \alpha 5 \text {, or } \beta 1 \text { monoclonal antibodies block the } \\
\text { adhesion }\end{array}$ & [48] \\
\hline & $\begin{array}{l}\text { Rabbit FLS cultured on the substrate containing Fn fragment show upregulated expression of } \\
\text { procollagenase and prostromelysin }\end{array}$ & [51] \\
\hline Vitronectin (Vn) & $\begin{array}{l}\text { FLS adhering to } V n \text { shows higher proliferative ability in response to PDGF. Adhesion to Vn through } \\
\text { integrin } \alpha v \text { downregulates collagenase expression in human FLS }\end{array}$ & [47] \\
\hline \multirow[t]{3}{*}{ Tenascin (Tn) } & FLS synthesize Tn & [52] \\
\hline & RA-FLS bind more strongly to Tn than normal FLS; monoclonal antibodies to integrin $\beta 1$ block adhesion & [48] \\
\hline & $\begin{array}{l}\text { Rabbit FLS cultured on Tn/Fn mixed substrate show increased expression of collagenase, stromelysin, } \\
\text { the } 92 \mathrm{kDa} \text { gelatinase, and c-fos }\end{array}$ & [53] \\
\hline \multirow[t]{2}{*}{ Hyaluronan (HA) } & Synthesized by FLS, degraded by macrophage-like lining cells & [54] \\
\hline & HA inhibits proliferation of FLS & [55] \\
\hline Decorin & Modulates MMP-1 gene expression of rabbit FLS when present on the substrate with $\mathrm{Vn}$ or Fn fragment & {$[56]$} \\
\hline Perlecan & Involved in adhesion and growth of FLS & [57] \\
\hline Collagen type I & $\begin{array}{l}\text { FLS adhering to collagen type I show higher proliferative ability in response to PDGF. Adhesion to } \\
\text { collagen type I through integrin } \beta 1 \text { downregulates the collagenase expression in human FLS }\end{array}$ & [47] \\
\hline \multirow[t]{5}{*}{ Collagen type IV } & Synthesized by FLS & [58] \\
\hline & RA-FLS bind more strongly to collagen type IV than normal FLS & [48] \\
\hline & monoclonal antibodies to integrin $\beta 1$ block adhesion & [59] \\
\hline & Degraded by MMP-2, MT-MMP & [60] \\
\hline & Degraded by matrilysin & [61] \\
\hline
\end{tabular}

CS-1, connecting sequence 1; ED-A, extra domain-A; MMP, matrix metalloproteinase; MT, membrane type; PDGF, platelet derived growth factor; $\mathrm{RA}$, rheumatoid arthritis.

passive event, but can affect one or both of the interacting cells. Such events have been proven to be dependent on cell-cell contact by the lack of effect of cell culture supernatant (ie in the physical absence of one of the interacting cells). Similar conclusions have been drawn based on the inhibition of the observed effect upon use of physical barriers between the interacting cells (eg their separation by membranes). This abolishes cellular events dependent on cell-cell interaction. Many of these heterotypic interactions are dependent on the $\beta_{2}$ (CD18) integrins, shown by the use of blocking antibodies. Adherens junctions have been reported between fibroblasts. Another relatively new and unexpected finding is that gap junctions are present in fibroblasts. Built up from transmembrane proteins, connexons, gap junctions allow the spread of small molecular second messagers like $\mathrm{Ca}^{2+}$ and cAMP from one cell to another. Transfection of fibroblasts with the 'receptor for hyaluronic acid-mediated motility' regulates gap junctional intercellular communication and connexin- 43 expression, affecting focal adhesion and cytoskeleton organization, with various secondary effects on motility, growth and transformation (Table 4) [62-73]. 
Table 4

Direct cell-cell interactions between fibroblasts and other cell types

\begin{tabular}{|c|c|c|}
\hline Cell type & Effect & Reference \\
\hline Macrophage & Direct transfer (of FITC-dextran, mannose BSA gold) from macrophages to fibroblasts & {$[62,63]$} \\
\hline \multirow[t]{3}{*}{ Neutrophil } & $\begin{array}{l}\text { Neutrophil adhesion to fibroblasts is increased by PMA treatment of neutrophils and by IL- } 1 \alpha \\
\text { or TNF- } \alpha \text { treatment of fibroblasts }\end{array}$ & [64] \\
\hline & Fibroblasts provide directional guidance to adhering neutrophils & [65] \\
\hline & $\begin{array}{l}\text { PAF and IL-8 enhance neutrophil adhesion to and motility of adhered neutrophils along } \\
\text { fibroblasts, respectively, in an integrin } \beta_{2} \text { dependent process }\end{array}$ & [66] \\
\hline \multirow[t]{2}{*}{ Lymphocyte } & Fibroblasts synthesize IL- $1 \alpha$, IL-1 $\beta$, IL- 6 and ICE & [67] \\
\hline & Fibroblast mediated synthesis of collagen type I and type III is decreased & [68] \\
\hline Eosinophil & Activated eosinophils adhere to fibroblasts: this adhesion is inhibited with RGDS & [69] \\
\hline \multirow[t]{3}{*}{ Mast cell } & Formation of mast pseudopods and their translocation to fibroblast surface & {$[70]$} \\
\hline & Mast cell stimulates fibroblast proliferation after cell-cell contact in an IL-4 dependent manner & [71] \\
\hline & Gap junctions between the mast cell and fibroblast are possible & {$[72]$} \\
\hline Osteoblast-like cells & $\begin{array}{l}\text { Osteoblast-like cells stimulate fibroblast proliferation (regulation of osteoprogenitor cell } \\
\text { proliferation?) }\end{array}$ & [73] \\
\hline
\end{tabular}

BSA, bovine serum albumen; ICE, interleukin-1 $\beta$-converting enzyme; IL, interleukin; FITC, fluorescein isothiocyanate; PAF, platelet-activating factor; PMA, phorbol myristate acetate; RGDS, arginyl-glycyl-aspartyl-serine; TNF, tumor necrosis factor.

\section{Conclusion}

It has been claimed that the rheumatoid arthritis synovial fibroblasts differ from their nonrheumatoid counterparts in terms of growth rate, life span, glycolytic metabolism, synthesis of hyaluronan and sulfated glycosaminoglycans, acid hydrolase activities, and metabolic and structural mitochondrial proteins [1]. The rheumatoid fibroblasts show a sustained and distinct morphology and pattern of gene activation [74,75], and might represent nonrheumatoid fibroblasts, but might also be phenotypically altered chondrocytes or bone marrow derived stem cells. These differences between the normal and the inflammatory synovium may be due to a selection pressure in the synovial mileau, where water- and lipid-soluble stimuli, cyclic loading, shear stress, ECM contacts and direct cell-cell contacts more or less permanently modulate the phenotype and function of fibroblast-like cells in the synovial lining, stroma and pannus.

\section{References}

1. Konttinen YT, Saari H, Santavirta S, Antti-Poika I, Sorsa T, Nykanen P, Kemppinen P: Synovial fibroblasts. Scand J Rheumatol 1988, 76 (suppl):95-103.

2. Springer TA: Adhesion receptors of the immune system. Nature 1990, 346:425-434.

3. Callard RE, Gearing AJH: The Cytokine Facts. London: Academic Press; 1994.

4. Ohgoda O, Sakai A, Koga H, Kanai K, Miyazaki T, Niwano Y: Fibroblast-migration in a wound model of ascorbic acid-supplemented three-dimensional culture system: the effects of cytokines and malotilate, a new wound healing stimulant, on cell-migration. J Dermatol Sci 1998, 17:123-131.
5. Ware MF, Wells A, Lauffenburger DA: Epidermal growth factor alters fibroblast migration speed and directional persistence reciprocally and in a matrix-dependent manner. J Cell Sci 1998, 111: 2423-2432.

6. Yule KA, White SR: Migration of $3 T 3$ and lung fibroblasts in response to calcitonin gene-related peptide and bombesin. Exp Lung Res 1999, 25:261-273.

7. Andresen JL, Ehlers N: Chemotaxis of human keratocytes is increased by platelet-derived growth factor-BB, epidermal growth factor, transforming growth factor-alpha, acidic fibroblast growth factor, insulin-like growth factor-I, and transforming growth factor-beta. Curr Eye Res 1998, 17:79-87.

8. Postlethwaite AE, Seyer JM, Kang AH: Chemotactic attraction of human fibroblasts to type I, II, and III collagens and collagenderived peptides. Proc Natl Acad Sci USA 1978, 75:871-875.

9. Dean JW III, Blankenship JA: Migration of gingival fibroblasts on fibronectin and laminin. J Periodontol 1997, 68:750-757.

10. Senior RM, Griffin GL, Mecham RP, Wrenn DS, Prasad KU, Urry DW: Val-Gly-Val-Ala-Pro-Gly, a repeating peptide in elastin, is chemotactic for fibroblasts and monocytes. J Cell Biol 1984, 99:870-874.

11. Postlethwaite AE, Snyderman R, Kang AH: Generation of a fibroblast chemotactic factor in serum by activation of complement. $J$ Clin Invest 1979, 64:1379-1385.

12. Kondo $\mathrm{H}$, Yonezawa $\mathrm{Y}$, Ito $\mathrm{H}$ : Interferon-beta, an autocrine cytokine, suppresses human fetal skin fibroblast migration into a denuded area in a cell monolayer but is not involved in the age-related decline of cell migration. Mech Ageing Dev 1996, 87:141-153.

13. Adelmann-Grill BC, Hein R, Wach F, Krieg T: Inhibition of fibroblast chemotaxis by recombinant human interferon gamma and interferon alpha. J Cell Physiol 1987, 130:270-275.

14. Hein R, Mensing $H$, Muller PK, Braun-Falco O, Krieg T: Effect of vitamin $A$ and its derivatives on collagen production and chemotactic response of fibroblasts. Br J Dermatol 1984, 111:37-44.

15. Mensing $\mathrm{H}$, Czarnetzki BM: Generation and characterization of a neutrophil-derived inhibitor of fibroblast chemotaxis. Arch Dermatol Res 1986, 278:184-189.

16. Bitterman PB, Wewers MD, Rennard SI, Adelberg S, Crystal RG: Modulation of alveolar macrophage-driven fibroblast proliferation by alternative macrophage mediators. J Clin Invest 1986, 77:700-708.

17. Basilico C, Moscatelli D: The FGF family of growth factors and oncogenes. Adv Cancer Res 1992, 59:115-165. 
18. Brinckerhoff CE: Morphologic and mitogenic responses of rabbit synovial fibroblasts to transforming growth factor beta require transforming growth factor alpha or epidermal growth factor. Arthritis Rheum 1983, 26:1370-1379.

19. Denk PO, Knorr M: Effect of heparin on human corneal fibroblast proliferation in vitro with and without growth factor stimulation. Graefes Arch Clin Exp Ophthalmol 1999, 237:342-347.

20. Ludwig CU, Menke A, Adler G, Lutz MP: Fibroblasts stimulate acinar cell proliferation through IGF-I during regeneration from acute pancreatitis. Am J Phys 1999, 276:193-198.

21. Kratz G, Lake M, Ljungstrom K, Forsberg G, Haegerstrand A, Gidlund $M$ : Effect of recombinant IGF binding protein-1 on primary cultures of human keratinocytes and fibroblasts: selective enhancement of IGF-1 but not IGF-2-induced cell proliferation. Exp Cell Res 1992, 202:381-385.

22. Gitter BD, Koehneke EM: Retinoic acid potentiates interleukin-1and fibroblast growth factor-induced human synovial fibroblast proliferation. Clin Immunol Immunopathol 1991, 61:191-120.

23. Haynes JH, Johnson DE, Mast BA, Diegelmann RF, Salzberg DA, Cohen IK, Krummel TM: Platelet-derived growth factor induces fetal wound fibrosis. J Pediatr Surg 1994, 29:1405-1408.

24. Jutley JK, Wood EJ, Cunliffe WJ: Influence of retinoic acid and TGF-beta on dermal fibroblast proliferation and collagen production in monolayer cultures and dermal equivalents. Matrix 1993, 13:235-241.

25. Yu F, Itoyama Y, Kira J, Fujihara K, Kobayashi T, Kitamoto T, Suzumura A, Yamamoto N, Nakajima Y, Goto I: TNF-beta produced by human T lymphotropic virus type l-infected cells influences the proliferation of human endothelial cells and fibroblasts. J Immuno/ 1994, 152:5930-5938.

26. Hanemaaijer R, Sorsa T, Konttinen YT, Ding Y, Sutinen M, Visser H, van Hinsbergh VW, Helaakoski T, Kainulainen T, Ronka H, Tschesche H, Salo $\mathrm{T}$ : Matrix metalloproteinase- 8 is expressed in rheumatoid fibroblasts and endothelial cells. J Biol Chem 1997, 272:31504-31509.

27. Deleuran BW, Chu CQ, Field M, Brennan FM, Katsikis P, Feldmann M, Maini RN: Localization of tumor necrosis factor receptors in the synovial tissue and cartilage-pannus junction in patients with rheumatoid arthritis. Implications for local actions of tumor necrosis factor alpha. Arthritis Rheum 1992, 35:1170-1178.

28. Gross SS, Wolin MS: Nitric oxide: pathophysiological mechanisms. Annu Rev Physiol 1995, 57:737-769.

29. Sakurai H, Kohsaka H, Liu MF, Higashiyama H, Hirata $Y$, Kanno K, Saito I, Miyas N: Nitric oxide production and inducible nitric oxide synthase expression in inflammatory arthritides. J Clin Invest 1995, 96:2357-2363.

30. Mclnnes IB, Leung BP, Field M, Wei XQ, Huang FP, Sturrock RD, Kinninmonth A, Weidner J, Mumford R, Liew FY: Production of nitric oxide in the synovial membrane of rheumatoid and osteoarthritis patients. J Exp Med 1996, 184:1519-1524.

31. Nussler AK, Billiar TR: Inflammation, immunoregulation, and inducible nitric oxide synthase. J Leukoc Biol 1993, 54:171-178.

32. Borderie D, Hilliquin P, Hernvann A, Lemarechal H, Menkes CJ, Ekindjian OG: Apoptosis induced by nitric oxide is associated with nuclear p53 protein expression in cultured osteoarthritic synoviocytes. Osteoarthritis Cartilage 1999, 7:203-213.

33. Mitchell JA, Larkin S, Williams TJ: Cyclooxygenase-2: regulation and relevance in inflammation. Biochem Pharmacol 1995, 50:1535-1542.

34. Wu KK: Inducible cyclooxygenase and nitric oxide synthase. Adv Pharmacol 1995, 33:179-207.

35. DiBattista JA, Martel-Pelletier J, Fujimoto N, Obata K, Zafarullah M, Pelletier JP: Prostaglandins E2 and E1 inhibit cytokine-induced metalloprotease expression in human synovial fibroblasts. Mediation by cyclic-AMP signalling pathway. Lab Invest 1994, 71:270-278.

36. Takahashi S, Inoue T, Higaki M, Mizushima Y: Cyclooxygenase inhibitors enhance the production of tissue inhibitor-1 of metalloproteinases (TIMP-1) and pro-matrix metalloproteinase 1 (proMMP-1) in human rheumatoid synovial fibroblasts. Inflamm Res 1997, 46:320-323.

37. Agro A, Langdon C, Smith F, Richards CD: Prostaglandin E2 enhances interleukin 8 (IL-8) and IL- 6 but inhibits GMCSF production by IL-1 stimulated human synovial fibroblasts in vitro. J Rheumatol 1996, 23:862-868.

38. Panchenko MV, Farber HW, Korn JH: Induction of heme oxygenase1 by hypoxia and free radicals in human dermal fibroblasts. $A m \mathrm{~J}$ Physiol Cell Physiol 2000, 278:C92-C101.

39. Maines MD: Heme oxygenase: function, multiplicity, regulatory mechanisms, and clinical applications. FASEB J 1988, 2:2557-2568.
40. Melillo G, Taylor LS, Brooks A, Musso T, Cox GW, Varesio L: Functional requirement of the hypoxia-responsive element in the activation of the inducible nitric oxide synthase promoter by the iron chelator desferrioxamine. J Biol Chem 1997, 272:12236-12243.

41. Frisch SM, Vuori K, Ruoslahti E, Chan-Hui PY: Control of adhesiondependent cell survival by focal adhesion kinase. J Cell Biol 1996, 134:793-799.

42. Shiozawa K, Shiozawa S, Shimizu S, Fujita T: Fibronectin on the surface of articular cartilage in rheumatoid arthritis. Arthritis Rheum 1984, 27:615-622.

43. Hino K, Shiozawa S, Kuroki Y, Ishikawa H, Shiozawa K, Sekiguchi K, Hirano H, Sakashita E, Miyashita K, Chihara K: EDA-containing fibronectin is synthesized from rheumatoid synovial fibroblast-like cells. Arthritis Rheum 1995, 38:678-683.

44. Müller-Ladner U, Elices MJ, Kriegsmann JB, Strahl D, Gay RE, Firestein GS, Gay S: Alternatively spliced CS-1 fibronectin isoform and its receptor VLA-4 in rheumatoid arthritis synovium. J Rheumatol 1997, 24:1873-1880.

45. Konttinen YT, Li T-F, Mandelin J, Liljestrom M, Sorsa T, Santavirta S, Virtanen I: Increased expression of EMMPRIN in rheumatoid synovium. Arthritis Rheum 2000, 43:275-280.

46. Nozawa-Inoue K, Ajima H, Takagi R, Maeda T: Immunocytochemical demonstration of laminin in the synovial lining layer of the rat temporomandibular joint. Arch Oral Biol 1999, 44:531-534.

47. Sarkissian M, Lafyatis R: Integrin engagement regulates proliferation and collagenase expression of rheumatoid synovial fibroblasts. J Immunol 1999, 162:1772-1779.

48. Rinaldi N, Schwarz-Eywill $M$, Weis $D$, Leppelmann-Jansen $P$ Lukoschek M, Keilholz U, Barth TF: Increased expression of integrin on fibroblast-like synoviocytes from rheumatoid arthritis in vitro correlates with enhanced binding to extracellular matrix proteins. Ann Rheum Dis 1997, 56:45-51.

49. Wolf J, Carsons S: Fibronectin mediates anchorage-dependent focus formation in cultured human synoviocytes. Semin Arthritis Rheum 1992, 21:387-392.

50. Carsons S, Wolf J: Interaction between synoviocytes and extracellular matrix in vitro. Ann Rheum Dis 1995, 54:413-416.

51. Damsky C, Tremble $P$, Werb Z: Signal transduction via the fibronectin receptors: do integrins regulate matrix remodeling? Matrix 1992, 1 (suppl 1):184-191.

52. McCachren SS, Lightner VA: Expression of human tenascin in synovitis and its regulation by interleukin-1. Arthritis Rheum 1992, 35: 1185-1196.

53. Tremble $\mathrm{P}$, Chiquet-Ehrismann $\mathrm{R}$, Werb Z: The extracellular matrix ligands fibronectin and tenascin collaborate in regulating collagen gene expression in fibroblasts. Mol Biol Cell 1994, 5:439-453.

54. Asari A, Kuriyama S, Kominami E, Uchiyama Y: Cytochemical localization of hyaluronic acid in human synovium with special reference to its possible process of degradation. Arch Histol Cytol 1995, 58:65-76.

55. Goldberg RL, Toole BP: Hyaluronate inhibition of cell proliferation. Arthritis Rheum 1987, 30:769-778.

56. Huttenlocher A, Werb Z, Tremble P, Huhtala P, Rosenberg L, Damsky $\mathrm{CH}$ : Decorin regulates collagenase gene expression in fibroblasts adhering to vitronectin. Matrix Biol 1996, 15:239-250.

57. Dodge GR, Boesler EW, Jimenez SA: Expression of the basement membrane heparin sulfate proteoglycan (perlecan) in human synovium and in cultured human synovial cells. Lab Invest 1995 73:649-657.

58. Schneider M, Voss B, Rauterberg J, Menke M, Pauly T, Michlke RK, Friemann J, Gerlach U: Basement membrane proteins in synovial membrane. Clin Rheumatol 1994, 13:90-97.

59. Okada Y, Morodomi T, Enghild JJ, Suzuki K, Yasui A, Nakanishi I, Salvesen $\mathrm{G}$, Nagase $\mathrm{H}$ : Matrix metalloproteinase 2 from human rheumatoid synovial fibroblasts. Purification and activation of the precursor and enzymic properties. Eur J Biochem 1990, 194:721-730.

60. Seiki M: Membrane-type matrix metalloproteinases. APMIS 1999, 107:137-143.

61. Wilson CL, Matrisian LM: Matrilysin: an epithelial matrix metalloproteinase with potentially novel functions. Int J Biochem Cell Biol 1996, 28:123-136.

62. Dean MF, Cooper JA, Stahl P: Cell contact and direct transfer between co-cultured macrophages and fibroblasts. J Leukoc Biol 1988, 43:539-546.

63. Dean MF, Rodman J, Levy M, Stahl P: Contact formation and transfer of mannose BSA gold from macrophages to cocultured fibroblasts. Exp Cell Res 1991, 192:536-542. 
64. Shock A, Laurent GJ: Adhesive interactions between fibroblasts and polymorphonuclear neutrophils in vitro. Eur J Cell Biol 1991, 54:211-216.

65. Behzad AR, Chu F, Walker DC: Fibroblasts are in a position to provide directional information to migrating neutrophils during pneumonia in rabbit lungs. Microvasc Res 1996, 51:303-316.

66. Burns AR, Simon SI, Kukielka GL, Rowen JL, Lu H, Mendoza LH, Brown ES, Entman ML, Smith CW: Chemotactic factors stimulate CD18-dependent canine neutrophil adherence and motility on lung fibroblasts. J Immunol 1996, 156:3389-3401.

67. Murakami S, Hino E, Shimabukuro $Y$, Nozaki T, Kusumoto $Y$, Saho T, Hirano $F$, Hirano $H$, Okada $H$ : Direct interaction between gingival fibroblasts and lymphoid cells induces inflammatory cytokine mRNA expression in gingival fibroblasts. J Dent Res 1999, 78:6976.

68. Rezzonico R, Burger D, Dayer JM: Direct contact between T lymphocytes and human dermal fibroblasts or synoviocytes down-regulates types I and III collagen production via cell-associated cytokines. J Biol Chem 1998, 273:18720-18728.

69. Shock A, Rabe KF, Dent G, Chambers RC, Gray AJ, Chung KF, Barnes PJ, Laurent GJ: Eosinophils adhere to and stimulate replication of lung fibroblasts 'in vitro'. Clin Exp Immunol 1991, 86:185190.

70. Greenberg G, Burnstock G: A novel cell-to-cell interaction between mast cells and other cell types. Exp Cell Res 1983, 147:1-13

71. Trautmann A, Krohne G, Brocker EB, Klein CE: Human mast cells augment fibroblast proliferation by heterotypic cell-cell adhesion and action of IL-4. J Immunol 1998, 160:5053-5057.

72. Oliani SM, Girol AP, Smith RL: Gap junctions between mast cells and fibroblasts in the developing avian eye. Acta Anat (Basel) $1995,154: 267-271$.

73. van der Plas A, Nijweide PJ: Cell-cell interactions in the osteogenic compartment of bone. Bone 1988, 9:107-111.

74. Ritchlin C, Dwyer E, Bucala R, Winchester R: Sustained and distinctive patterns of gene activation in synovial fibroblasts and whole synovial tissue obtained from inflammatory synovitis. Scand J Immunol 1994, 40:292-298.

75. Zvaifler NJ, Tsai V, Alsalameh S, von Kempis J, Firestein GS, Lotz M: Pannocytes: distinctive cells found in rheumatoid arthritis articular cartilage erosions. Am J Pathol 1997, 150:1125-1138.

Authors' affiliations: Yrjö Konttinen (Department of Anatomy, Institute of Biomedicine, and Department of Oral Medicine, Institute of Dentistry, University of Helsinki, and Department of Oral Medicine, Surgical Hospital, The Helsinki and Uusimaa Health Care Concern, Helsinki, Finland), Tian-Fang Li and Jing-Wen Xu (Department of Anatomy, Institute of Biomedicine, and Department of Oral Medicine, Surgical Hospital, The Helsinki and Uusimaa Health Care Concern, Helsinki, Finland), Mika Hukkanen and Ismo Virtanen (Department of Anatomy, Institute of Biomedicine, University of Helsinki, Helsinki, Finland), and Jian Ma (Department of Anatomy, Institute of Biomedicine, and Department of Oral Medicine, Institute of Dentistry, University of Helsinki, Helsinki, Finland),

Correspondence: Professor Yrjö T Konttinen, Department of Oral Medicine, Surgical Hospital, The Helsinki and Uusimaa Health Care Concern, Kasarmikatu 11-33, FIN-00130 Helsinki, Finland.

Tel: +358 9 1918477; Fax: +3589 1918576;

E-mail: yrjo.konttinen@helsinki.fi 